\title{
Must there be a "war" against coronavirus?
}

\author{
PALLAVI ROHELA, ANANT BHAN, DIVYA RAVINDRANATH, DEVI LEENA BOSE, SOUMITRA PATHARE
}

\begin{abstract}
The ongoing Covid-19 pandemic is marked not only by rapid spread of the causative virus, SARS CoV-2, but also by the spread of war-like narratives. Leaders of different countries have compared the pandemic response to being at war.

In this argument paper, the authors take the stance that frequent public pronouncements of metaphors of war do more harm than good, especially when they percolate through the societal psyche and the healthcare system. We describe how the narrative of war has further dented social cohesion, an important social determinant of health, and created a rift in the healthcare system at a time of immense crisis. We express concern that such systemic instability threatens to drive a deeper wedge into the already precarious physician-patient relationship, while also putting the future of medicine at stake. Finally, we provide alternative metaphors for use in the communication strategy. The suggested metaphors are gentler, drawn from sports and ecology, and emphasise the need for cooperation and solidarity at multiple levels.
\end{abstract}

Keywords: Covid-19, war metaphor, stigmatisation, social cohesion, physician-patient relationship

\section{Introduction}

The first few cases of Covid-19 were reported to the World Health Organization by China on December 31, 2019, classified at the time as pneumonia of unknown viral etiology. The situation has evolved dramatically since then. The causative virus, named SARS-CoV-2, spread to 114 countries over the next two and a half months. As a result, the World Health Organization declared Covid-19 to be a pandemic on March 11, 2020 (1-5). As of June 23, 2020, there are 8, 936, 337 confirmed cases of Covid-19 around the world. India currently has the

Authors: Pallavi Rohela (pallaviprashast@gmail.com), MPH student, University of Massachusetts, Amherst, USA; Anant Bhan (anantbhan@ gmail.com), Researcher, Global Health, Bioethics and Health Policy, Bhopal, MP, INDIA; Divya Ravindranath (divyarrs@gmail.com), Researcher, Indian Institute of Human Settlements, Bengaluru, Karnataka, INDIA: Devi Leena Bose (devilina.bose@gmail.com), Senior Manager- Advocacy, Policy and Communication, IAVI, New Delhi, INDIA; Soumitra Pathare (corresponding author - spathare@cmlhp.org), Director, Centre for Mental Health Law and Policy, Indian Law Society, ILS Law College campus, Law College Road, Pune 411004 INDIA.

To cite: Rohela P, Bhan A, Ravindranath D, Bose DL, Pathare S. Must there be a "war" against coronavirus? Indian J Med Ethics. 2020 Jul-Sep; 5(3) NS: 222-6. DOI:10.20529/IJME.2020.070.

Published online on June 25, 2020.

Manuscript Editor: Sandhya Srinivasan

(c) Indian Journal of Medical Ethics 2020 fourth highest caseload in the world, with the official statistics putting the Covid-19 toll in India at 14,011 deaths so far $(6,7)$.

Concurrent with the rapid global spread of the novel coronavirus, has been the spread of discourses globally that make repeated references to "war." Leaders of different countries and the United Nations' Secretary-General have compared the response to the pandemic to a military battle, with the President of the United States likening himself to a "wartime" president $(8,9)$. The situation in India is not very different. Phrases like "war against coronavirus", "Covid warriors" and "Corona fighters" have become commonplace terms in the political and media narrative, and adjectives and prefixes of choice for many service providers at this time. Official advisories have used the word "deployed" instead of the usual "posted" when referring to healthcare workers and adorned them with the adjective "frontline", evoking battlefront imagery (10). Televised addresses to the nation regarding the pandemic have included mentions of the 1971 Indo-Pak war and the eighteen days' war that lies at the core of the great Indian epic, the Mahabharata $(11,12)$.

Public pronouncements by authorities which are replete with war metaphors may appear necessary for boosting public morale and unity. However, several negative consequences occur when the war narrative percolates through the societal psyche and the healthcare system. Some of them have been highlighted by a subset of the authors in the recent past (13). The current paper offers a further expansion of those arguments, to persuade healthcare professionals (HCPs) of the inappropriateness of war-centric language.

\section{Why use metaphors?}

Metaphors provide a mental model for understanding abstract and/or novel concepts in terms of more familiar and concrete ones. Depending on the metaphors used, they can positively or negatively influence thoughts and actions (14). They can provide a ready recourse for health communication given the low levels of scientific literacy in the general public. Among the metaphors frequently used are those that are related to war.

The war metaphor has gained wide usage in connection with disease over time, as writers likened illness to an invasion of the human body (15). Advancements in antibiotics and other medical technologies made infectious diseases more curable and less life-threatening, conveying a sense of the possibility of "victory" over disease, leading to the calls for "war on cancer" and "war on HIV" (16). Thus, the Covid-19 pandemic is not the first time that the war metaphor has been used in health messaging.

Early exposure to the concept of war from folklore, history and media ensures that the war metaphor is easily understood 
by the general public (17). Any effort that needs large scale mobilisation of communities with limited resources can begin to be associated with war. The "fear appeal" inherent in the war metaphor can have beneficial effects, given its potential to spur the desired behavioural changes with speed, pushing the need for alignment and adherence to a singular narrative, the one that is the government's. However, the war metaphor can, and has hurt too, as described in the subsequent paragraphs.

\section{Problems with using the war metaphor}

The war narrative has made India's pandemic response problematic on multiple fronts. It has resulted in stigmatisation of patients, neglect of non-Covid care, and instability within the healthcare system, as shown below:

\section{Creation of an epidemic of fear, discrimination and stigma}

It is a natural human reaction to experience fear in the face of a virus that is spreading rapidly, causing multiple deaths in a short period and for which, definitive treatments are not yet available. Being surrounded by a war-like narrative has only compounded and propagated this fear further. It is important to understand that fighting a war unites one group against the other, necessitating the search for an enemy $(18,19)$. In the war against coronavirus, the supposed "enemy" - the virus - is invisible to the naked eye. Hence, in the zeal to "fight" the disease, individuals who have Covid-19 or are viewed as potential carriers of the disease have ended up as "enemies" and targets, as illustrated by several incidents.

Soon after Lockdown-I was announced, there were multiple reports of HCPs and airline crew being forcefully evicted by their landlords with little notice with no arrangements of alternative accommodation (20). Those who had symptoms of Covid-19 or tested positive for the disease experienced vigilantism and ostracism from their gated societies, as did international returnees (21-23). Helplessly accustomed to violence inside hospitals for long, HCPs became victims of violence outside hospitals as well $(24,25)$.

For people at the receiving end of such hostility, the stigma and mental health ailments that may follow may well outlive the pandemic. There may be further breakdown in social cohesion, increasingly considered as a key domain of the social determinants of health (26-28). Additionally, even where care facilities are available, the intense paranoia around Covid-19 and the fear of getting infected has been keeping people from seeking the timely healthcare they may need, be it for Covidrelated symptoms or non-Covid conditions (29).

\section{Acceptability of collateral damage}

An overlooked consequence of war-driven narratives is the over mobilisation of resources in one direction, to the detriment of other areas of concern. The laserfocused approach to "defeat" the coronavirus paved the way for continued massive diversion of hospital resources and staff towards Covid care. It has negatively impacted healthcare delivery for other health conditions including non-communicable diseases. Non Covid-19 patients, with conditions like heart disease, diabetes, stroke, tuberculosis, kidney disease requiring regular dialysis, to mention a few, illnesses that constitute the bulk of India's epidemiological disease burden, have become the unwitting "collateral damage" in healthcare's war against the coronavirus $(30,31)$. Planned treatments of people visiting tertiary health centres in metropolitan cities from different parts of the country, including cancer care, were stopped, without their being given a chance to move back to their distant homes (32). Similarly, ante-natal care and post-partum care have been negatively impacted, along with outreach immunisation services $(33,34)$.

\section{Breakdown of the therapeutic alliance: Refusal of care}

Healthcare typically works by building alliances between different parts and different players in the health system. An effective alliance between physicians and patients, among different healthcare professionals at different stages of training and seniority levels, and between private and government health sectors in mixed health systems like ours, is the cornerstone of a functional health system. On the other hand, "war" creates an adversarial environment which threatens the healthcare and therapeutic alliance.

In recent weeks, patients are being refused care even in the government sector, and the Delhi state government came out with orders restricting access to care based on geography of origin, perhaps couching it in terms of a triage exercise with priority setting (35). After all, when it is a "war", all rules can be bent to emerge victorious and claim that critical care was provided successfully to "our own" (defined as those belonging to a certain geography).

Patients have been reported as intentionally withholding their Covid-status or travel history from HCPs. Such behaviour is indicative of the stigma around the disease, the distrust of quarantine facilities, should one have to go there after testing positive, and also, suspicion that they may not receive care if they told the complete truth $(36,37)$. There have also been reports of doctors refusing to examine patients (33). This overwhelming fear of contracting the infection, heightened by the war narrative, threatens to devalue the core of the provider-patient bond. It has the potential to drive a deeper wedge into already weakened doctor-patient relationships, and aggravate distrust of the health system.

\section{Soldiers instead of professionals}

The assertion that the public health crisis presented by the pandemic is a "war" tends to equate India's physicians, nurses, and other allied staff with members of the armed forces. The expectation of silence, adherence to orders, and stoicism that is maintained in the defence forces, is thus transposed onto HCPs too (13).

Speaking up about the shortage and subpar quality of personal protective equipment (PPE) has come to be met with punitive actions $(38,39)$. Physicians and nurses are professionals with a right to demand a safe workplace. The 
false equivalence with soldiers who will go into battle based on a command, even with no questions asked, intentionally overlooks this basic right.

In the West, the upcoming field of narrative medicine has started examining whether the military language used for medicine and HCPs, creates unrealistic expectations of the latter, causing them to be viewed as "failures" in case they succumb to the infection (40). This insight should explain the rationale behind the show-cause notices issued by the administration in India, asking HCPs to "explain how they got infected in spite of wearing PPE." Such notices increase stress and lower the morale of India's healthcare force (41). It is imperative to note that the administration's perception of PPE, not as a protective shield that lowers the risk of infection by creating more barriers in the route of transmission, but as a "weapon" for "subjugating the virus" is not very different from the language used in this context by the Indian Medical Association. The IMA, while appealing for more provision of PPE in adequate numbers, had said that "no nation sends its army to war without weapons."This points to the internalisation of the war metaphor by elements of the country's healthcare workforce, oblivious to its dangers (42).

\section{Alternatives}

To inspire multi-spherical planning, more coordinated responses and minimise stigmatisation, it is important that the language surrounding the pandemic is corrected. There are other metaphors from sport and ecology which may achieve the same goal without the negatives associated with the war metaphor.

Viewing our response to the Covid-19 pandemic as a cricket test match strengthens the understanding that this public health crisis demands teamwork, solidarity, and dynamic strategies, responsive to emerging information, and transparent data (43). The sports metaphor has been suggested by the WHO Director-General Tedros Adhanom Ghebreyesus too. He has referred to handling the pandemic by thinking of it as a football game that requires the "defence" of lockdown and also the "attack" of testing, tracing, and isolation (44). Other world leaders have demonstrated how health communication free of war metaphors is possible. In Germany, the messaging has been straightforward with reliance on phrases like "historic task" and "challenge before humanity" (45). In New Zealand, the leadership's emphasis on kindness and teamwork has helped in ensuring a stigmafree environment (46). Referring to the situation as a "dance" of accommodation reinforces the understanding that people need to learn to live with the virus in circulation. Practices of good respiratory etiquette, physical distancing, and self-isolation upon becoming symptomatic, would need rigorous adherence till effective medication and/or vaccine are developed (47). "Journey" and "orchestra" have also been suggested as alternative metaphors for use, as they emphasise the extended period of time over which the issue will have to be dealt with, the anticipation of obstacles along the way, and the coordination required among multiple groups of people in the planning and execution of working solutions, with more synchrony and rhythm, than chaos and confusion (48).

\section{Conclusion}

Calling it a "war" has made our pandemic response shortsighted. It has further dented the social cohesion within the general society, stigmatising many, creating a rift between different participants and sectors of the healthcare system, with a risk of further deterioration of physician-patient relationship.

Importantly, the future of medicine as a profession has also been put at risk. The moral injury and mental health repercussions that HCPs are experiencing, as a result of having to turn away patients due to hospital protocols or unavailability of beds, being ostracised due to their potential for transmitting the infection, and expectations of continuing to provide care despite poor quality protective equipment being provided, merits wider acknowledgement and redressal (49). Opinion pieces from professionals in other countries hint at the increased possibility of disillusionment with medicine as a profession, with more HCPs currently in practice openly expressing the desire to exit from it, given the callous attitudes of the administration (50).

India's entry into the fifth phase of the national lockdown, with varying relaxations in levels of public activity permitted, signals a subtle acceptance that the Covid-19 pandemic was never a "war" to be fought in the first place. It is important that calls for global, regional, national and local solidarity and cooperation replace metaphors of war. The time is now ripe, not only for evidence-based public health interventions but also for employing gentler and more appropriate metaphors in public health communication, if at all they must continue to be used.

\section{References}

1. Jinyi Y. Wuhan Municipal Health and Health Commission notified the pneumonia epidemic. Hubei Daily. 2020 Jan 1 [cited 2020 Jun 10]. [Chinese]. Available from: https://epaper.hubeidaily.net/pc/ content/202001/01/content_15040.html

2. Ting Q. Experts say preliminary progress has been made in the etiology identification of the unexplained viral pneumonia epidemic in Wuhan. Xinhua Net. 2020 Jan 09 [cited 2020 Jun 10]. [Chinese]. Available from: http://www.xinhuanet.com/202001/09/C_1125438971.htm

3. Gorbalenya AE, Baker SC, Baric RS et al. The species Severe acute respiratory syndrome-related coronavirus: classifying 2019-nCoV and naming it SARS-CoV-2. Nat Microbiol. 2020 Mar 02 [cited 2020 Jun 10]; 5: 536-44. Available from: https://www.nature.com/articles/s41564020-0695-z

4. World Health Organization. Naming the coronavirus disease (COVID-19) and the virus that causes it. 2020 Feb 11 [cited 2020 Jun 10]. Available from: https://www.who.int/emergencies/diseases/ novel-coronavirus-2019/technical-guidance/naming-the-coronavirusdisease-(covid-2019)-and-the-virus-that-causes-it

5. Ghebreyesus TA.WHO Director-General's opening remarks at the media briefing on COVID-19 - 11 March 2020. World Health Organization. 2020 Mar 11 [cited 2020 Jun 10]. Available from: https://www.who.int/ $\mathrm{dg} / \mathrm{speeches/detail/who-director-general-s-opening-remarks-at-the-}$ media-briefing-on-covid-19---11-march-2020

6. WHO Coronavirus Disease (Covid-19) Dashboard. Available from : $\quad$ https://covid19.who.int/?gclid=EAlalQobChMlq 
fV7un56QIVxn0rCh3DcAifEAAYASAAEgJF3PD BwE

7. Ministry of Health and Family Welfare, Govt of India. Covid-19 India statistics. Available from: https://www.mohfw.gov.in/

8. Broning M. Coronavirus: No, we're not at war. Politico. 2020 Apr 14 [cited 2020 Jun 11] Available from: https://www.politico.eu/article/coronavirusno-were-not-at-war/

9. Reuters. 'Invisible enemy': Trump says he is 'wartime president' in coronavirus battle - video 2020 Mar 23 [cited 2020 Jun 11]. Available from : https://www.theguardian. com/world/video/2020/mar/23/invisible-enemy-trumpsays-he-is-wartime-president-in-coronavirus-battle-video

10. Indian Council of Medical Research. Revised advisory on the use of hydroxychloroquine (HCQ) as prophylaxis for COVID-19 infection (in supersession of previous advisory dated 23rd March, 2020). 2020 May 22 [cited 2020 Jun 11]. Available from : https://www.mohfw. gov.in/pdf/Revisedadvisoryontheuseofhydroxychloroquineasproph ylaxisforSARSCOVID19infection.pdf

11. Modi N. PM refers to Mahabharata war in fighting against coronavirus... Watch this video to find out more! [Video].You Tube. 2020 Mar 25 [cited 2020 Jun 11]. Available from: https://www.youtube.com/ watch?v=JUldeG4LqPY

12. Modi N. Coronavirus | PM Modi proposes 'janta curfew': Watch full speech. [Video, at 12:03]. YouTube. 2020 Mar 19 [cited 2020 Jun 11]. Available from: https://www.youtube.com/watch?v=8aD9-Y4EHhc

13. Rohela P, Pathare $S$, Bhan A. 'War' on coronavirus is hurting doctors, health staff and you. New Indian Express. 2020 Apr 7 [cited 2020 Jun 11]. Available from : https://www.newindianexpress.com/opinions/2020/ apr/07/war-on-coronavirus-is-hurting-doctors-health-staff-andyou-2126724.html

14. Landau MJ, Arndt J, Cameron LD. Do metaphors in health messages work? Exploring emotional and cognitive factors. J Exp Soc Psychol. 2018 Jan[cited 2020 Jun 12];(74), 135-49. Available from: https://www. sciencedirect.com/science/article/abs/pii/S0022103117302597

15. Wright JM. Poetry has linked war and disease for centuries. The Conversation. 2020 Apr 26 [cited 2020 Jun 12]. Available from: https:// theconversation.com/poetry-has-linked-war-and-disease-forcenturies-136141

16. Lederberg J. Infectious history. Science. 2000 Apr 14 [cited 2020 Jun 13]; 288(5464):287-93. Available from: https://science.sciencemag.org/ content/288/5464/287.summary

17. Flusberg SJ,MatlockT,Thibodeau PH.War metaphors in public discourse Metaphor and Symbol. 2018 Jan 3[cited 2020 Jun 13]; 33(1):1-18 Available from: https://www.tandfonline.com/doi/full/10.1080/109264 88.2018.1407992

18. Hagstrom J. Stop calling Covid-19 a war. Washington Post. 2020 Apr 20 [cited 2020 Jun 14]. Available from: https://www.washingtonpost.com/ outlook/2020/04/20/stop-calling-covid-19-war/

19. Mongoven $A$. The war on disease and the war on terror: $A$ dangerous metaphorical nexus? Camb Q Healthc Ethics, 15 (4): 403 - 16. 2006 Aug 09 [cited 2020 Jun 14]. Available from: https://www.cambridge.org/ core/journals/cambridge-quarterly-of-healthcare-ethics/article/waron-disease-and-the-war-on-terror-a-dangerous-metaphorical-nexus/5 50809F6F6CDB3DFC1604DBD8469A574

20. Jha F, Sirur S. 'Stranded, facing eviction' - doctors, air hostesses harassed over coronavirus fear. Print. 2020 Mar 24 [cited 2020 Jun 13]. Available from : https://theprint.in/india/stranded-facing-evictiondoctors-air-hostesses-harassed-over-coronavirus-fear/387410/

21. Times News Network. Coronavirus scare: No clarity on protocols, Noida residents call cops to 'report' people returning from abroad. Times of India. 2020 Mar 18 [cited 2020 Jun 14]. Available from: https:// timesofindia.indiatimes.com/city/noida/no-clarity-on-protocolsresidents-call-cops-to-report-people-returning-from-abroad/ articleshow/74682074.cms

22. Bhatia S. Coronavirus and the neo-tribes of an increasingly fractured India. Wire. 2020 Mar 26 [cited 2020 Jun 14]. Available from: https:// thewire.in/society/coronavirus-rwa-residential-colony-stigma

23. Maitreyi MLM. Lockdown and social distancing changes life for residents in gated communities. Hindu. 2020 Mar 27 [cited 2020 Jun 14].
Available from : https://www.thehindu.com/news/cities/Hyderabad/ life-changes-for-residents-of-gated-communities/article31180543.ece

24. Pandey V. Coronavirus: India doctors 'spat at and attacked'. BBC News. 2020 Apr 3 [cited 2020 Jun 13]. Available from: https://www.bbc.com/ news/world-asia-india-52151141

25. Saxena A, Manral MS. Delhi: Man assaults Safdarjung doctor, sister accuses them of spreading virus. Indian Express. 2020 Apr 10 [cited 2020 Jun 13]. Available from : https://indianexpress.com/article/cities/ delhi/delhi-doctors-out-to-buy-fruit-assaulted-accused-of-spreadingcoronavirus-6353862/

26. Kawachi I, Berkman L. Social cohesion, social capital, and health. In: Berkman LF, Kawachi I, editors. Social epidemiology. New York: Oxford University Press; 2000. p. 174-90.

27. Chuang YC, Chuang KY, Yang TH. Social cohesion matters in health. Int J Equity Health. 2013 Oct 28 [cited 2020 Jun 14]. Available from: https:// equityhealthj.biomedcentral.com/articles/10.1186/1475-9276-12-87

28. Office of Disease Prevention and Health Promotion. Social cohesion, healthy people. 2020 [cited 2020 Jun 14]. Available from : https://www. healthypeople.gov/2020/topics-objectives/topic/social-determinantshealth/interventions-resources/social-cohesion\#6

29. Sparshita. 'Stigma still attached to Covid-19, many fear getting tested': AllMS director. Hindustan Times. 2020 May 09 [cited 2020 Jun 14]. Available from : https://www.hindustantimes.com/india-news/stigmais-still-attached-to-covid-19-many-fear-to-get-tested-aiims-director/ story-QkezKjWt6yvqscq2FNaXPJ.html

30. World Health Organization. COVID-19 significantly impacts health services for noncommunicable diseases. World Health Organization. 2020 Jun 1 [cited 2020 Jun 14]. Available from : https://www.who.int/ news-room/detail/01-06-2020-covid-19-significantly-impacts-healthservices-for-noncommunicable-diseases

31. Singh P. Non-COVID-19 Patients Are Paying the Price of India's Efforts Against the Coronavirus. Science. Wire [Internet].2020 May 3 [cited 2020 May 30]. Available from: https://science.thewire.in/health/healthcarenon-coronavirus-patients/

32. Indo Asian News Service. COVID-19 tales: Lockdown's been a nightmare for outstation patients at Delhi AlIMS. New Indian Express. 2020 May 29 [cited 2020 May 31] Available from: https://www.newindianexpress. com/cities/delhi/2020/may/29/covid-19-tales-lockdowns-been-anightmare-for-outstation-patients-at-delhi-aiims-2149644.html

33. Shrivastava S, Sivakami M. Obstetric violence during COVID-19 Is yet another challenge for Indian women. The Wire. 2020 Apr 23 [cited 2020 Jun 14]. Available from: https://thewire.in/rights/women-covid-19obstetric-violence

34. Das S. India's infant immunization drive comes to a halt over Covid-19 Fear. Business Standard. 2020 Apr 25 [cited 2020 Jun 16]. Available from : https://www.business-standard.com/article/economy-policy/ india-s-infant-immunisation-drive-comes-to-a-halt-over-covid-19fear-120042201411_1.html

35. ET Bureau.Delhi hospitals only for Delhiites till crisis over.Economic Times. 2020 Jun 08 [cited 2020 Jun 14]. Available from : https://economictimes. indiatimes.com/news/politics-and-nation/delhi-hospitals-only-fordelhiites-till-crisis-over-arvind-kejriwal/articleshow/76253092.cms

36. Bhat S. Covid- 19: Authorities fear people hiding travel history may spread disease in J\&K. NewsClick. 2020 Mar 27 [cited 2020 Jun 14]. Available from : https://www.newsclick.in/COVID-19-Authorities-FearPeople-Hiding-Travel-History-Spread-Disease-J\%26K

37. Press Trust of India. Nagpur doctors quarantined after patient's hidden COVID-19 details revealed. Deccan Herald. 2020 Mar 31 [cited 2020 Jun 14]. Available from: https://www.deccanherald.com/national/west/ nagpur-doctors-quarantined-after-patients-hidden-covid-19-detailsrevealed-819538.htm

38. Reinstate doctor fired for alleged misconduct: medical bodies to govt. Outlook. 2020 Apr 18 [cited 2020 Jun 1]. Available from: https://www. outlookindia.com/newsscroll/reinstate-doctor-fired-for-allegedmisconduct-medical-bodies-to-govt/1806274

39. Doctor who raised concerns over PPE shortage admitted to mental hospital. BBC.com. 2020 May 21 [cited 2020 Jun 1]. Available from: https://www.bbc.com/news/world-asia-india-52719110

40. Stephens S. How doctors use stories to help them cope with the coronavirus crisis. Los Angeles Times. 2020 Jun 10 [cited 2020 Jun 14]. Available from : https://www.latimes.com/science/story/2020-06-10/ 
doctors-use-narrative-medicine-to-cope-with-the-coronavirus

41. Sharma JP. Coronavirus pandemic: AlIMS Delhi doctors sound alarm bells against govt apathy. Outlook. 2020 May 02 [cited 2020 Jun 14]. Available from : https://www.outlookindia.com/website/story/indianews-coronavirus-pandemic-aiims-delhi-doctors-sound-alarm-bellsagainst-govt-apathy/351933

42. Newsmeter Network. Doctors will stay home if assaults continue:IMA on Chennai incident. Newsmeter. 2020 Apr 20 [2020 Jun 16]. Available from: https://newsmeter.in/doctors-will-stay-home-if-assaults-continue-imaon-chennai-incident/

43. Shankar M, Bhan A. Covid-19 fight is a test match, not a T20. Here's what India needs to do to win. The Print. 2020 Apr 22 [cited 2020 Jun 1] Available from : https://theprint.in/science/covid-19-fight-is-a-testmatch-not-a-t20-heres-what-india-needs-to-do-to-win/406207/

44. Ghebreyesus TA.WHO Director-General's opening remarks at the media briefing on COVID-19 - 23 March 2020. World Health Organization. 2020 Mar 23 [cited 2020 Jun 14]. Available from: https://www.who.int/ $\mathrm{dg} / \mathrm{speeches/detail/who-director-general-s-opening-remarks-at-the-}$ media-briefing-on-covid-19---23-march-2020

45. Paulus D. How politicians talk about coronavirus in Germany, where war metaphors are avoided. The Conversation. 2020 May 22 [cited 2020
Jun 14]. Available from : https://theconversation.com/how-politicianstalk-about-coronavirus-in-germany-where-war-metaphors-areavoided-137427

46. Cousins S. New Zealand eliminates Covid-19. Lancet. 2020 May 09 [cited 2020 Jun 1]. Available from https://www.thelancet.com/journals/lancet/ article/PIIS0140-6736(20)31097-7/fulltext

47. Hurst DK. The hammer and the dance. Plexus Institute website. 2020 Apr 19 [cited 2020 Jun 14]. Available from: https://plexusinstitute. org/2020/04/19/crushing-innovation-with-coercive-bureaucracy-thecase-of-the-coronavirus/

48. Pathare S. Role of language during a pandemic. Webinar on Covid-19. DBT Wellcom. 2020 Apr 22 [cited 2020 Jun 1]. Available from: https:// www.indiaalliance.org/news/420

49. Gupta P. How COVID-19 is affecting the mental health of doctors and nurses? Financial Express. 2020 May 28 [cited 2020 May 31]. Available from: https://www.financialexpress.com/lifestyle/health/how-covid-19is-affecting-the-mental-health-of-doctors-and-nurses/1973490/

50. Harper M. When this war is over, many of us will leave medicine. Elemental. medium.com. 2020 Apr 24 [cited 2020 May 30]. Available from: https://elemental.medium.com/when-this-war-is-over-many-ofus-will-leave-medicine-86a274b5a627 